\title{
TITLE:
}

\section{Altered plasticity of the human motor cortex in Parkinson's disease(Abstract_要旨)}

\author{
AUTHOR(S): \\ Ueki, Yoshino
}

\section{CITATION:}

Ueki, Yoshino. Altered plasticity of the human motor cortex in Parkinson's disease. 京都大 学, 2006, 博士(医学)

\section{ISSUE DATE:}

2006-03-23

URL:

http://hdl.handle.net/2433/143858

\section{RIGHT:}




\section{【321】}

氏 名植亲美㭆

学位(専攻分野) 博士（医、学）

学位記番号医博第 2978 号

学位授与の日付平成 18 年 3 月 23 日

学位授与の要件 学 位 規 則第 4 条第 1 項 該 当

研究科・専攻医学研究科脳統御医科学系専攻

学位論文題目 Altered plasticity of the human motor cortex in Parkinson's disease

（パーキンソン病に扔けるヒト運動皮質の脳可塑性の変化）

論文調查委員 教授金子武嗣教授橋本信夫教授高橋良輔

\section{論 文 内 容 の 要旨}

背景 ドパミンが前頭前野や基底核での神経可塑性に重要な役割を担うことが，動物実験で報告されている。しかし，大 脳皮質 - 基底核回路は運動統御に関っており, 神経可塑性が重要であるにもかかわらず, ヒト運動皮質の脳可塑性とドパミ ンの関連は知られていない。近年, 経頭蓋的磁気刺激法（Transcranial magnetic stimulation:TMS）と末梢神経電気刺激 を組み合わせることで，脳可塑性をヒト運動皮質に誘導する手法が開発された（連合性対刺激法）。本研究では，ヒトのド 一パミン系神経回路障害の代表疾患であるパーキンソン病の患者群を対象として, 連合性対刺激法によって誘導される運動 皮質の可塑性を検討した。

目的 パーキンソン病患者にTMS を用いた連合性対刺激法を適応して,ドパミンがヒト運動皮質の脳可塑性に関連する かを解明する。

対象及び方法 パーキンソン病患者18名と相応する年齢群の健常高齢者11名を対象とした。パーキンソン病患者は，ドパ ミン製剤を 12 時間休薬した状態 (オフ条件) で検查を行い，内 10 名に扔いては，内服後 2 時間以内の状態 (オン条件)でも 㭘査を行った。運動機能を含めた臨床的重症度は Unified Parkinson’s Disease Rating Scale（UPDRS）を用いて評価した。 運動皮質に脳可塑性を誘導する手法として，連合性対刺激法を用いた。連合性対刺激法では，被験者の右上中神経を手根部

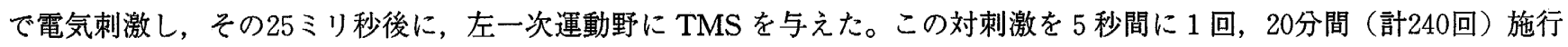
した。運動皮質の脳可塑性を定量化するために, 連合性対刺激の前後で, 単発のTMSにより誘発される運動誘発電位を計 測した。運動誘発電位の振幅増加率を計測し, 正常高齢者と各条件下のパーキンソン病患者で運動皮質の興奮性の変化を比 較検討した。

結果 正常高齢者では, 連合性対刺激後に, 運動誘発電位が1.55倍へ増大したが, オフ条件のパーキンソン病患者では, 運動誘発電位の増大を認めなかった（振幅増加率＝0.96）。これに対して, オン条件の運動誘発電位は, 連合性対刺激の前 後で有意に増大した（振幅増加率＝1.25）。また，オフ条件では，運動誘発電位の振幅増加率とUPDRS の運動機能重症度 との間に逆相関関係を示した。

考察 ドパミン製剤の内服により運動皮質の脳可塑性の低下が有意に改善されたことと, 運動皮質の脳可塑性の低下が， パーキンソン病の運動機能障害の程度と相関を認めたことは, ドパミン久如が運動皮質の脳可塑性の低下に関連しているこ とを強く示唆する。パーキンソン病では筋強剛, 振戦, 頞動などの運動症状だけでなく, 運動学習の障害も認められること が知られている。また, 運動学習の生理学的基礎には運動皮質などの脳可塑性があるという報告もある。したがって, 本研 究で示されたドパミンによる運動皮質の脳可塑性の制御は，運動学習の制御に関連していると推測される。

結論 パーキンソン病患者では, 連合性対刺激法によって生じる運動皮質の脳可塑性が低下していることを発見した。ド パミンが運動皮質の脳可塑性の制御に重要な役割を果たすと考えられる。 


\section{論文審 査 の 結 果の要旨}

本研究の目的は,ドパミンがヒト運動皮質の可塑性に関連するかを経頭蓋的磁気刺激法（Transcranial Magnetic Stimulation：TMS）を用いて解明することである。パーキンソン病患者18名と健常高齢者11名を被験者とした。パーキン ソン病患者は，ドパミン製剤を 12 時間休薬した状態（オフ条件）で検查を行い，内 10 名は薬剤内服後 2 時間以内の状態（オ ン条件）でも検查を行った。運動皮質の可塑性変化を誘導する手法として，右正中神経電気刺激の 25 ミリ秒後に刺激部位に

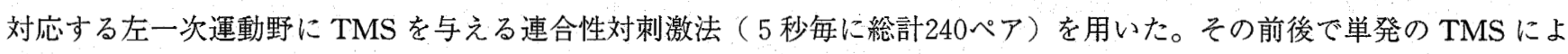
り誘発される運動誘発電位の振幅を計測し, 振幅比を算出することで運動皮質の脳可塑性を定量化した。その結果, 健常高 齢者では連合性対刺激後に運動誘発電位の振幅が1.55倍へ増大したが，オフ条件のパーキンソン病患者では増大を認めず （振幅比=0.96）, オン条件では有意に増大した（振幅比=1.25）。また, オフ条件では, 運動誘発電位の振幅比と臨床的な 運動機能重症度との間に逆相関関倸を示した。以上から，ドパミン久如が運動皮質の可塑性の低下に関連していることが示 唆された。こうした大脳皮質の脳可塑性の異常は, パーキンソン病患者でみられる運動学習などの高次機能障害とも関連し ている可能性がある。

以上の研究は，ヒト運動皮質の可塑性におけるドパミンの機能の解明に寄与するところが多い。したがって，本論文は博 士 (医学) の学位論文として価值あるものと認める。なお，本学位授与申請者は，平成18年1月27日実施の論文内容とそれ に関連した試問を受け，合格と認められたものである。 